\section{Short term tests can predict potential carcinogens, says study}

RESULTS of a unique international study to evaluate tests for the detection of chemical carcinogens were released in London last week. They confirm that there are shortterm tests that can be used to predict carcinogenic activity. No simple assay or battery of tests is readily apparent as bestsuited for assessing carcinogenicity; however, the coordinating committee of the study believes that the day is nearer when such a battery can be assembled to screen out potential carcinogenic chemicals.

The international programme for the evaluation of short-term tests for carcinogenicity began three years ago as a joint venture by the UK Medical Research Council (MRC) and Health and Safety Executive. Scientists at ICI Central Toxicology Laboratory (CTL) were asked to participate and the programme was later joined by researchers at the US National Institute of Environmental Health Sciences (NIEHS), who were keen to broaden the scope of the study to the level of a truly international trial of assay systems. Additional support and finance for an expanded programme was solicited and eventually provided by the US Environmental Protection Agency and National Cancer Research Institude in Japan.

The aim of the study, according to the coordinating committee chairman Dr Frederick J de Serres of NIEHS, was to examine the performance of various shortterm tests which have been used in attempts to distingush between known carcinogens and known non-carcinogens. Although may of the thirty tests used in the study are based on the ability of bacterial, fungal or mammalian cells to mutate, de Serres was insistent that the tests under scrutiny were being evaluated as "predictors of carcinogenic activity" and not just as tests for examining the mutagenic properties of chemicals.

It is well known that short-term tests can be fickle, giving better results for one class of chemical than another. It is equally true that many of the tests evaluated so far have been studied with the researcher knowing both the identity of the chemical being tested and its carcinogencity in animals. To eliminate this built-in bias the 60 or so laboratories participating in the international programme were sent coded samples, the identities of which were only revealed after investigators had submitted their final results. 42 chemicals, 25 carcinogens and 17 non-carcinogens from as wide a range of chemical classes as possible, were selected on the basis of data available concerning their carcinogenic properties in animals (see Nature, 274, 740, (1978)).

The results presented last week were a summary of discussions of two meetings held in March and October of this year to assess the findings. On the basis of the data evaluated so far the coordinating committee concludes that the most effective tests are those using bacteria such as Salmonella and Escherichia coli. Tests using strains of Salmonella to detect mutagenic chemicals were first developed by Dr Bruce Ames at the University of California (the 'Ames' test). Although Ames personally declined to participate in the study, some twelve laboratories using this test did take part. The so-called 'Ames sub-set' of bacteria tests were found to be highly predictive of potential chemical carcinogens.

But the bacterial-based assay do not detect carcinogens in every case. No positive result is obtained for the potent carcinogen hexamethylphosphoramide (HMPA), whereas a positive result is obtained for both fungal assay systems using yeast and mammalian cell tests. All tests give such false negatives and false positives too; the committee concludes, therefore, that the most effective results can be obtained by using a battery of tests.

According to Dr John Ashby of CTL, the committee considers the bacterialbased tests to be the most reliable, but the mammalian cell tests are necessary to "fill in the holes"'; and assays based on whole animal systems such as the sex-linked recessors lethal tests using Drosophila or the mouse-sister-chromatid exchange tests are 'good arbiters' of the other two, but are not yet ready to be "worked up into full test systems"'.

Professor Bryn Bridges of the MRC Cell Mutation Unit at Sussex University made the point that more research is required to study the nuts and bolts of the assay systems if short-term tests are to be used as a screening net in potential carcinogens. Because there is still much to be learned, Bridges warns against the temptation facing some government regulating authorities to lay down cast-iron rules for the application of tests. If this happens, says Bridges, it will 'fossilise' the tests and limit their effectiveness.

Aware of the commercial potential of their recommendations the coordinating committee is being deliberately cautious about recommending any one assay system. Many commercial laboratories, already involved in routine testing, could cash in on the findings of this study. It is too early, says the committee, to identify the appropriate battery of tests to be used on the basis of a study restricted to fortytwo chemicals. Nevertheless, it is clear that the results of this study will have considerable influence on regulatory authorities. It will published in full by June 1980.

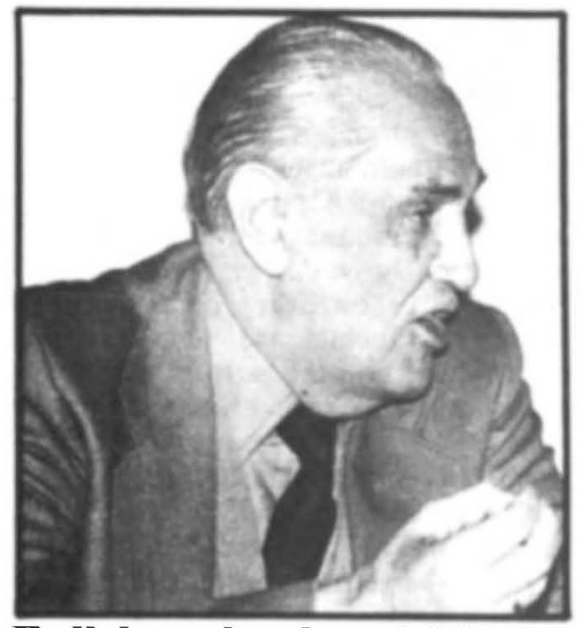

Polish animal nutritionist refused passport

Dr Jan Kielanowski, (above) a member of the Polish Academy of Sciences and an acknowledged expert on pig rearing was last week refused a passport to Britain to chair a symposium on "Future perspectives in pig nutrition', organised by the British Nutrition Society. Dr Kielanowski is head of the Polish unofficial 'Society of Academic Courses' (the "Flying University" - see Nature 6 December, page 543). In May of this year, together with Dr Edward Lipinski, an economist, he attempted to bring before the General Assembly of the Polish Academy of Sciences a motion calling for the abolition of press censorship and greater academic liberty.

\section{Yugoslavia changes nuclear site after protests}

YUGOSLAV energy planners have decided to site Croatia's second nuclear power station at Prevlaka on the river Sava, near Zagreb. This decision follows concerted local protests against the site originally projected, the island of Vir near Zadar on the coast. Plans for a station on Vir have not, however, been abandoned. In all, four nuclear power stations with a total capacity of $3500 \mathrm{MW}$ are to be built in Croatia within the next 20 years. Croatia has coal reserves for only thirty years and will have exhausted its hydroelectric potential by the end of the century.

Last July, R Pavlovic, director of the Croation Electricity Board announced that even if the second station should be transferred to an inland site, all future nuclear power stations would have to be built on the coast, since only the sea can provide sufficient water for them. Last month's decision by the Croatian Association of Electric Power enterprises to build the second station at Prevlaka included a resolution to continue research work at Vir. Certain industrial interests in Croatia are anxious to develop along the coast some industry other than tourism, which they see, at best, as too dependent on factors external to the Yugoslav economy.

Vera Rich 